\title{
Nutritional Qualities of Cocoa Pod Husk Treated with Bioconversion and or Provision of Nitrogen Sources in the Rumen
}

\author{
Syahrira, Hartutik ${ }^{\mathrm{b}}$, Kusmartono $^{\mathrm{b}}$, \& Damrya,** \\ ${ }^{a}$ Faculty of Animal Science and Fishery, Tadulako University, Palu 94117, Indonesia

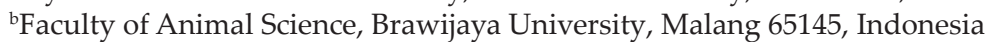 \\ (Received 16-08-2017; Reviewed 11-10-2017; Accepted 27-11-2017)
}

\begin{abstract}
The objective of this study was to investigate the effects of bioconversion using Phanerochaete chrysosporium and Pleurotus ostreatus and or inclusion of Moringa oleifera leaves and urea in the rumen on cocoa pod husk digestibility and fermentation in the rumen. There were 4 treatments tested: (1) $100 \%$ untreated cocoa pod husk (UCPH), (2) 55\% UCPH $+43.7 \%$ M. oleifera $+1.30 \%$ urea (UCPHMU), (3) $100 \%$ bioconverted cocoa pod husk (BCPH), and (4) $55 \%$ BCPH $+44.5 \mathrm{M}$. oleifera $+0.5 \%$ urea (BCPHMU). Each of the treatments was replicated three times. Variables observed were dry matter and organic matter digestibilities and degradabilities, rumen VFA and ammonia concentrations, gas production, and calculated microbial biomass yields. Results indicated that the treatment increased dry matter $(P<0.001)$ and organic matter $(P<0.01)$ digestibility, with the highest for the BCPHMU and the lowest for the UCPH. The treatments also increased dry matter and organic matter degradability in the rumen $(P<0.001)$, with the highest for the BCPHMU, followed by the UCPHMU, and then by the BCPH and the lowest was $\mathrm{UCPH}$. The treatment affected rumen ammonia concentration $(P=0.01)$, the highest value was found for the BCPHMU followed with UCPHMU and BCPH. Microbial biomass synthesis was affected $(P<0.001)$ by the treatment and it was always higher when nitrogen was provided (UCPHMU and BCPHMU). Total VFA concentration or total gas production was higher for BCPHMU compared to other treatments. It can be concluded that nutritional quality of cocoa pod husk can be improved by either bioconversion with $P$. chrysosporium and $P$. ostreatus or inclusion of $M$. oleifera and urea in the rumen, but the best improvement can be obtained by the combination of bioconversion and provision of the nitrogen sources in the rumen.
\end{abstract}

Keywords: biological treatment, cocoa pod husk, digestibility, fermentation, white rot fungi

\section{ABSTRAK}

Tujuan penelitian ini adalah untuk mempelajari pengaruh biokonversi menggunakan Phanerochaete chrysosporium dan Pleurotus ostreatus dan atau penambahan Moringa oleifera (daun kelor) dan urea ke dalam rumen pada kecernaan dan degradasi kulit buah kakao di dalam rumen. Ada 4 perlakuan yang dicobakan: (1) 100\% kulit buah kakao tanpa perlakuan (UCPH), (2) 55\% UCPH + 43,7\% M. oleifera + 1,30\% urea (UCPHMU), (3) 100\% kulit buah kakao biokonversi (BCPH), dan (4) 55\% BCPH + 44,5 M. oleifera $+0,5 \%$ urea (BCPHMU). Tiap perlakuan diulang 3 kali. Peubah yang diamati adalah kecernaan dan degradasi bahan kering dan bahan organik pakan, konsentrasi VFA dan amonia rumen, produksi gas, dan produksi biomassa mikrob. Hasil penelitian menunjukkan bahwa perlakuan meningkatkan kecernaan bahan kering $(P<0,001)$ dan bahan organik $(P<0,01)$, kecernaan tertinggi diperoleh pada BCPHMU dan terendah pada UCPH. Perlakuan juga meningkatkan $(P<0,001)$ keteruraian bahan kering dan bahan organik di dalam rumen, tertinggi pada BCPHMU, disusul oleh UCPHMU, BCPH, dan terendah pada UCPH. Perlakuan meningkatkan konsentrasi ammonia rumen $(P=0,01)$, tertinggi pada BCPHMU diikuti oleh UCPHMU dan BCPH. Hasil biomasa mikroba juga dipengaruhi oleh perlakuan $(P<0,001)$, dan hasil biomassa mikroba selalu lebih tinggi saat disediakan tambahan nitrogen di dalam rumen (UCPHMU dan BCPHMU). Konsentrasi total VFA atau produksi gas total pada BCPHMU lebih tinggi dibandingkan perlakuan lainnya. Disimpulkan bahwa kualitas nutrisi kulit buah kakao dapat diperbaiki, baik melalui biokonversi dengan $P$. chrysosporium dan $P$. ostreatus, maupun dengan penambahan $M$. oleifera dan urea ke dalam rumen, namun hasil terbaik diperoleh jika kedua perlakuan tersebut digabungkan.

Kata kunci: kulit buah kakao, perlakuan biologis, jamur pelapuk putih, kecernaan, fermentasi

*Corresponding author:

E-mail: damry_01@yahoo.com 


\section{INTRODUCTION}

Indonesia is the third largest cocoa producing country in the world after Ivory Coast and Ghana (Witjaksono \& Asmin, 2016). In 2016, the total area of cocoa plantation in Indonesia was estimated to be about 1.7 million hectares with a total cocoa production of 760,429 tonnes (DGEC, 2015). Assuming that cocoa pod husk constitutes about $75 \%$ of the whole cocoa fruit (Cruz et al., 2013), there was about 530,322 tones of cocoa pod husk produced in Indonesia in 2016. As a by-product of cocoa plantation industry, the cocoa pod husk is currently not being utilized optimally by farmers. The common practice regarding the cocoa pod husk is to leave it dried and rotten or use it as a mulching material for the cocoa plant itself.

Cocoa pod husk is a potential biomass that can be used as an animal feed resource, especially for ruminants (Puastuti \& Susana, 2014). However, the cocoa pod husk is known to have low nutritional properties such as high cellulose and hemicellulose contents (Suparjo et al., 2011; Daud et al., 2013). It also contains a considerable amount of lignin, i.e approximately $14.7 \%$ on dry matter basis (Daud et al., 2013), which is higher than that in rice straw. Inclusion of untreated cocoa pod husk in ruminant diets has been associated with low feed intakes and negative live weight gains (Saili et al., 2010).

Fermentative bioconversion of cocoa pod husk with white rot fungi seems to be a promising approach in attempt to increase its nutritional quality (Syahrir et al., 2013; Laconi \& Jayanegara, 2015; Yakin et al., 2016; Yakin et al., 2017). Laconi \& Jayanegara (2015) concluded that Phanerochaete chrysosporium, a species of white rot fungi capable of degrading lignin, was effective in improving the nutritive value of cocoa pod husk. In our previous study, we combined P. chrysosporium and Pleurotus ostreatus (another species of white rot fungi) and found that the two species acted synergistically in improving the nutritional properties of cocoa pod husk and its in vitro digestibility (Syahrir et al., 2013).

Moringa oleifera is a multipurpose tree that grows well across Indonesia. M. oleifera leaves are known to contain high crude protein and several studies have indicated positive animal responses when it is included as a protein source or feed component in ruminant diets (Adegun et al., 2011; Mendieta-Araica et al., 2011; Asaolu et al., 2012; Babeker \& Abdalbagi, 2015; Kholif et al.,
2015; Sultana et al., 2015; Babiker et al., 2017; Syarifuddin et al., 2017). According to Soliva et al. (2005), crude protein in $M$. oleifera leaves is highly fermentable and is therefore expected to be used as an ammonia source for microbial protein synthesis rather than providing rumen by-pass proteins to the animals. $M$. oleifera leaves are also high in sulphur-containing amino acids (Makkar \& Becker, 1997) and this may further benefit microbial protein synthesis in the rumen.

The objective of this study was to investigate the effects of bioconversion of cocoa pod husk with $P$. chrysosporium and $P$. ostreatus and or provision of $M$. oleifera and urea on its digestibility and fermentation in the rumen.

\section{MATERIALS AND METHODS}

\section{Treatments}

There were four dietary treatments tested consisting of untreated (UCPH) or bio-converted cocoa pod husk $(\mathrm{BCPH})$ with or without $M$. oleifera leaves and urea that were mixed at different proportions as shown in Table 1.

Bioconversion of cocoa pod husk was done by first mixing dried and finely ground cocoa pod husk $(10 \mathrm{~kg})$ with rice bran $(1.5 \mathrm{~kg}), \mathrm{CaCO} 3(0.15 \mathrm{~kg})$, urea $(10 \mathrm{~g})$, and water $(70 \%$ of the total weight). The mixture was placed in sealed bags and autoclaved at $121^{\circ} \mathrm{C}$ and $2 \mathrm{~atm}$ for $1 \mathrm{~h}$ and allowed to cool at the room temperature for 24-36h. It was then inoculated with either $P$. chrysosporium $\left(10^{7}\right.$ cells $\left./ g\right)$ and or P. ostreatus $\left(14.3 \times 10^{9} \mathrm{cfu} / \mathrm{mL}\right)$ in a room temperature until the bags were completely covered with mycelium (after about $20 \mathrm{~d}$ of fermentation). Different dosages of the two white rot fungi were used and tested for the effects on the chemical composition of the cocoa pod husk and its in vitro digestibility (Syahrir et al., 2013). The best results were found for the cocoa pod husk that was treated with $P$. chrysosporium $(8 \mathrm{~g} /$ $\mathrm{kg}$ ) and P. ostreatus ( $30 \mathrm{~g} / \mathrm{kg})$, and this was selected to be used in the current study.

\section{Experimental Procedures}

Feed dry matter and organic matter digestibilities were estimated with the two-step in vitro digestion technique of Tilley \& Terry (1963) as modified by van Der Meer (1980). The in vitro gas production technique

Table 1. Proportions of untreated and bio-converted cocoa pod husk, M. oleifera leaves and urea used in the treatments

\begin{tabular}{|c|c|c|c|c|c|c|}
\hline \multirow[b]{2}{*}{ Treatments } & \multicolumn{4}{|c|}{ Proportions $(\%)$} & \multicolumn{2}{|c|}{ Nutrients } \\
\hline & $\mathrm{UCPH}$ & $\mathrm{FCPH}$ & $\begin{array}{c}\text { Moringa oleifera } \\
\text { leaves }\end{array}$ & Urea & $\mathrm{DM}(\%)$ & $\mathrm{CP}(\% \mathrm{DM})$ \\
\hline $\mathrm{UCPH}$ & 100 & 0 & 0 & 0 & 86.8 & 5.06 \\
\hline UCPHMU & 55 & 0 & 43.7 & 1.3 & 86.5 & 16.1 \\
\hline ВСРН & 0 & 100 & 0 & 0 & 88.3 & 9.21 \\
\hline BCPHMU & 0 & 55 & 44.5 & 0.5 & 88.9 & 16.1 \\
\hline
\end{tabular}

Note: $\mathrm{UCPH}=$ untreated cocoa pod husk, UCPHMU= untreated cocoa pod husk + M. oleifera + Urea, $\mathrm{BCPH}=$ bio-converted cocoa pod husk, $\mathrm{BCPHMU=}$ bio-converted cocoa pod husk + M. oleifera + Urea. 
of Menke et al. (1979) as modified by Makkar et al. (1995) was employed to study rumen fermentation. Both experiments were run in a randomized block design with time of rumen fluid collection serving as the block. Each of the dietary treatments was replicated five times.

The rumen fluids were obtained from a fistulated cow (BW $\pm 450 \mathrm{~kg}$ ) maintained on a diet with a crude protein content of about $18 \%$. The diet consisted of a concentrate feed (a mixture of cooked soybean peel and rice bran) given at $1 \% \mathrm{BW}$ in the morning and $P$. purpureum that was given ad libitum after the concentrate. The fermentation lasted for $96 \mathrm{~h}$, and gas production was recorded at $0,2,4,816,24,36,48,72$, and 96 h of incubation. At the end of the $96 \mathrm{~h}$ incubation, the fermentation was terminated by immersing the fermentation syringes in ice and the contents were then centrifuged $(2.500$ rpm; $15 \mathrm{~min}$ ) to obtain the supernatants for $\mathrm{NH}_{3}$ and VFA analyses. Residues from two syringes were taken and prepared for determinations of DM and OM contents, while the remaining syringes were prepared for determination of microbial biomass synthesis (Blummel et al., 1997). For determination of microbial biomass, the syringe contents were transferred to a beaker glass and added with $100 \mathrm{~mL}$ of NDS solutions before it was refluxed for $60 \mathrm{~min}$. The solution was then filtered with filter crucible (porosity $0.01 \mathrm{~mm}$ ), washed with a least amount of hot water and followed with $75 \mathrm{~mL}$ of acetone and then dried in an oven $\left(105^{\circ} \mathrm{C} ; 4 \mathrm{~h}\right)$. Microbial biomass (mg) was calculated as the difference between apparent (substrate incubated-centrifuged residue) and true digestibility (substrate incubated-residu after NDS treatment).

\section{Chemical Analysis}

Feed dry matter content was determined by drying the feed samples to a constant weight at $60^{\circ} \mathrm{C}$. The concentration of $\mathrm{NH}_{3}$ in the fermentation supernatant was analysed with the Conway method (General Laboratory Procedure, 1966). One $\mathrm{mL}$ of each supernatant and 1 mL of saturated $\mathrm{NaOH}(40 \%)$ was placed oppositely on each side of the Conway disc. One $\mathrm{mL}$ of $\mathrm{H}_{3} \mathrm{BO}_{4}$ solution $(4 \%)$ as indicator was also placed in the middle of the disc before the disc was covered air-tightly. The disc contents were then mixed by a gentle shaking before it was allowed to stand in a room temperature for $24 \mathrm{~h}$. The contents was then back titrated with $0.01 \mathrm{~N} \mathrm{HCl}$ until its color turned back to its original color before the titration. Ammonia concentration was calculated as:

$\mathrm{NH}_{3}-\mathrm{N}(\mathrm{mg} / \mathrm{mL})=(\mathrm{mL} \mathrm{HCl}$ used $\times \mathrm{N} \mathrm{HCl}) \times \mathrm{NH}_{3} \mathrm{MW} \times$ $100^{-1} \mathrm{mg} / \mathrm{mL}$

The total VFA concentration was determined according to General Laboratory Procedure (1966) while that of individual VFA was done on a gas chromatographer (Shimadzu GC 9 AM equipped with a flame ionization detector and Shimadzu C-RGA integrator) according to Bachruddin (1996). For the individual VFA concentration, rumen fluid sample was first centrifuged (3,000 rpm; $10 \mathrm{~min}$ ) and $2 \mu \mathrm{L}$ of the supernatant was injected after the injection of a standard VFA solution.

\section{Calculations}

Gas production data were fitted to the exponential equation of $\mathrm{p}=\mathrm{a}+\mathrm{b}\left(1-\mathrm{e}^{-\mathrm{ct}}\right)$ (Ørskov \& McDonald, 1979), where $p$ represents gas volume at time $t$, a the gas produced from the soluble fraction, $b$ the gas produced from the insoluble but fermentable fraction, $a+b$ the potential gas production, and $\mathrm{c}$ the rate constant of gas production during incubation $\left(\% \mathrm{~h}^{-1}\right)$.

\section{Statistical Analysis}

One way analysis of variance for the randomized experimental block design was performed to evaluate effects of the treatments on variables observed, and significant difference among individual variable means were identified with Duncan's Multiple Range Test (Steel \& Torrie, 1991). Means differences were considered significant at $P<0.05$.

\section{RESULTS}

Nutrient contents of cocoa pod husk and nitrogen supplements are presented in Table 2 . In vitro dry matter and organic matter digestibilities of treatment feeds in the rumen fluid are shown in Table 3 while those of rumen fermentation parameters and gas productions are presented in Tables 4 and 5, respectively. Results indicated that dry matter and organic matter digestibilities among treatments differed one another, being the highest was found in the bioconverted cocoa pod husk added with $M$. oleifera and urea (BCPHMU) and the lowest was found in the untreated cocoa pod husk (UCPH). Digestibilities of dry matter $(48.0 \pm 1.03 \%)$ and organic matter $(48.0 \pm 1.97 \%)$ for the untreated cocoa pod husk provided with nitrogen sources (UCPHMU) were higher $(\mathrm{P}<0.01)$ than the corresponding values for the bioconverted cocoa pod husk $(\mathrm{BCPH})$ which was $46.0 \pm 1.09 \%$ and $45.0 \pm 1.65 \%$, respectively (Table 3 ).

Total VFA concentration, individual VFA proportion (Table 4), and total gas production (Table 5) were not affected by the treatments, except for the BCPHMU that were higher $(\mathrm{P}<0.05)$ than the other treatments. However, $\mathrm{NH}_{3}$ concentration for the BCPHMU was higher than the others, while the $\mathrm{NH}_{3}$ concentrations for the UCPHMU and the BCPH remained similar. Results

Table 2. Chemical compositions of feed ingredients (\%)

\begin{tabular}{lrrrr}
\hline \multicolumn{1}{c}{ Nutrients } & UCPH & BCPH & $\begin{array}{c}\text { M. oleifera } \\
\text { leaves }\end{array}$ & Urea \\
\hline Dry matter & 86.60 & 88.30 & 89.60 & 99.50 \\
Crude protein & 5.84 & 10.10 & 24.50 & 288.00 \\
Crude fiber & 44.40 & 38.40 & 18.30 & \\
Ether extracts & 2.75 & 2.56 & 4.40 & \\
Organic matter & 76.10 & 76.30 & 81.40 & \\
N-free extract & 23.51 & 25.24 & 34.20 & \\
\hline
\end{tabular}

Note: $\mathrm{UCPH}=$ untreated cocoa pod husk; FCPH= bio-converted cocoa pod husk. 
Table 3. Dry matter and organic matter digestibilities of feed treatments determined with two-steps in vitro incubation

\begin{tabular}{lcc}
\hline \multirow{2}{*}{ Treatments } & \multicolumn{2}{c}{ In vitro digestibility $(\%)$} \\
\cline { 2 - 3 } & Dry matter & Organic matter \\
\hline UCPH & $40.5 \pm 1.08^{\mathrm{a}}$ & $38.6 \pm 1.15^{\mathrm{a}}$ \\
UCPHMU & $48.0 \pm 1.03^{\mathrm{c}}$ & $48.0 \pm 1.97^{\mathrm{b}}$ \\
BCPH & $46.0 \pm 1.09^{\mathrm{b}}$ & $45.0 \pm 1.65^{\mathrm{b}}$ \\
BCPHMU & $49.9 \pm 0.68^{\mathrm{d}}$ & $50.2 \pm 2.65^{\mathrm{d}}$ \\
SEM & 0.06 & 0.18 \\
p-value & 0.000 & 0.001 \\
\hline
\end{tabular}

Note: $\mathrm{UCPH}=$ untreated cocoa pod husk, UCPHMU= untreated cocoa pod husk + M. oleifera + Urea, $\mathrm{BCPH}=$ bio-converted cocoa pod husk, BCPHMU = bio-converted cocoa pod husk $+M$. oleifera + Urea. Means in the same column with diferent superscripts differ significantly $(\mathrm{P}<0.05)$

for dry matter and organic matter degradabilities followed a similar trend with those for digestibilities in which the BCPHMU exhibited the highest values, followed by the UCPHMU, and then by the BCPH and the lowest one was UCPH. Microbial biomass synthesis was higher when nitrogen sources were provided in the rumen.

\section{DISCUSSION}

This study indicated that bioconversion of cocoa pod husk with a combination of $P$. chrysosporium and $P$.ostreatus had desirable effects on the nutritional values of the cocoa pod husk for ruminants. Significant higher dry matter and organic matter digestibilities were found in the bio-converted than in the untreated cocoa pod husk (BCPH vs UCPH; Table 3). There was about $14 \%$ increase in dry matter digestibility and $17 \%$ in organic matter digestibility due to the biological treatment of the cocoa pod husk. The increased feed digestibility found in the current study was consistent with the results reported previously (Syahrir et al., 2013) and this was probably related to the reduction in lignin contents of the cocoa pod husk after the bioconversion that had provided more sites for microbial fermentation in the rumen. Provision of nitrogen sources in the form of $M$. oleifea leaves and urea in the rumen also improved the dry matter and organic matter digestibilities. The improvement in digestibility due to the provision of nitrogen sources was higher (for dry matter) and similar (for organic matter) compared to that for the bioconversion treatment. Dry matter or organic matter digestibility was further improved by the combination of nitrogen source and bioconversion compared to each of these treatments perse.

Similar increases due to the bioconversion treatment and or the provision of nitrogen were also found

Table 4. Fermentation variables of feed treatments after $96 \mathrm{~h}$ of incubation

\begin{tabular}{|c|c|c|c|c|c|c|}
\hline \multirow{2}{*}{ Variables } & \multicolumn{4}{|c|}{ Treatments } & \multirow{2}{*}{ SEM } & \multirow{2}{*}{$\mathrm{p}$-value } \\
\hline & $\mathrm{UCPH}$ & UCPHMU & $\mathrm{BCPH}$ & BCPHMU & & \\
\hline Total VFA concentration (mM) & $60.50^{\mathrm{a}}$ & $62.70^{\mathrm{a}}$ & $62.00^{\mathrm{a}}$ & $63.40^{\mathrm{b}}$ & 0.12 & 0.04 \\
\hline Acetate, C2 (\%) & 75.40 & 74.00 & 74.40 & 74.00 & 0.08 & 0.07 \\
\hline Propionate, C3 (\%) & 15.40 & 15.90 & 16.30 & 15.90 & 0.05 & 0.06 \\
\hline Butyrate, C4 (\%) & 9.55 & 10.10 & 9.37 & 10.10 & 0.05 & 0.41 \\
\hline $\mathrm{C} 2: \mathrm{C} 3$ ratio & 5.09 & 4.67 & 4.58 & 4.64 & 0.04 & 0.45 \\
\hline $\mathrm{NH}_{3}$ concentration $(\mathrm{mM})$ & $8.65^{\mathrm{a}}$ & $9.29 \mathrm{~b}$ & $9.11^{\mathrm{b}}$ & $10.30^{c}$ & 0.11 & 0.01 \\
\hline DM degradability (\%) & $38.70^{\mathrm{a}}$ & $49.00^{c}$ & $45.70^{\mathrm{b}}$ & $51.40^{\mathrm{d}}$ & 0.12 & 0 \\
\hline OM degradability $(\%)$ & $37.00^{\mathrm{a}}$ & $48.10^{c}$ & $42.30^{\mathrm{b}}$ & $50.30^{\mathrm{d}}$ & 0.09 & 0 \\
\hline Microbial biomass synthesis (mg) & $82.20^{\mathrm{a}}$ & $85.10^{\mathrm{bc}}$ & $83.10^{\mathrm{ab}}$ & $86.00^{c}$ & 0.03 & 0 \\
\hline
\end{tabular}

Note: Means in the same row with diferent superscripts differ significantly $(\mathrm{P}<0.05)$.

Table 5. Total gas production and gas production variables after $96 \mathrm{~h}$ of incubation

\begin{tabular}{cccccccc}
\hline \multirow{2}{*}{ Variables } & \multicolumn{4}{c}{ Treatments } & \multirow{2}{*}{ SEM } & \multirow{2}{*}{ p-value } \\
\cline { 2 - 5 } & UCPH & UCPHMU & BCPH & BCPHMU & & & \\
\hline Gas production (mL/500 mg DM) & $69.3^{\mathrm{a}}$ & $69.9^{\mathrm{a}}$ & $70.4^{\mathrm{a}}$ & $73.2^{\mathrm{b}}$ & 0.08 & \\
$\mathrm{a}$ & -4.33 & -3.89 & -4.55 & -4.05 & nd & nd \\
$\mathrm{b}$ & 76.1 & 75.6 & 77.6 & 79.8 & 0.19 & 0.07 \\
$\mathrm{c}$ & 0.04 & 0.04 & 0.04 & 0.04 & 0 & 0.12 \\
\hline
\end{tabular}

Note: Means in the same row with diferent superscripts differ significantly $(\mathrm{P}<0.05)$. nd= not determind; $\mathrm{a}=$ the gas produced from the soluble fraction; $\mathrm{b}=$ the gas produced from the insoluble but fermentable fraction; and $\mathrm{c}=$ the rate constant of gas production during incubation $\left(\% \mathrm{~h}^{-1}\right)$. 
for dry matter and organic matter degradabilities of cocoa pod husk in the rumen (Table 4). Provision of $M$. oleifera and urea in the rumen increased rumen dry matter and organic matter degradabilities by $27 \%$ and $30 \%$, respectively, for the untreated cocoa pod husk; while the respective corresponding values for the bioconverted cocoa pod husk were $13 \%$ and $19 \%$. As for feed digestibility mentioned above, $M$. oleifera combined with urea exhibited higher effects on dry matter and organic matter degradabilities of cocoa pod husk in the rumen compared to the bioconversion treatment. The higher effect on rumen in-vitro dry matter digestibility of cocoa pod husk when added with urea than when treated with Phanerochaete chrysosporium was also found by Laconi \& Jayanegara (2015). Results of this study and those of Laconi \& Jayanegara (2015) show that provision of additional nitrogen sources to the rumen is probably more preferable approach to increase the cocoa pod husk digestibility than biologically treating it with white rot fungi.

The rumen fluid ammonia concentrations found in this study $(8.65-10.3 \mathrm{mM})$ were well above the optimum concentrations of $3.5-5.7 \mathrm{mM}$ for microbial protein synthesis in the rumen suggested by Satter \& Slyter (1974). However, other studies have found optimum microbial protein synthesis at higher rumen ammonia concentrations (Hume et al., 1970; Allen \& Miller, 1976). The ammonia concentrations were also similar or above the suggested rumen ammonia concentrations of $c a .8 .8$ $\mathrm{mM}$ for optimum rumen degradability of fibrous diets (Preston \& Leng, 1987). Based on the observed rumen ammonia concentrations in this study, rumen microbial growth and fermentation may have been proceeded normally.

While both provision of nitrogen sources in the rumen and bioconversion in this study increased the rumen ammonia concentrations significantly, higher microbial biomass production was only shown when M. oleifera and urea were added to either untreated or bio-converted cocoa pod husk (Table 4). It was probably that other forms of nitrogen than ammonia (amino acids and small peptide) were also available and beneficial for the growth and synthesis of rumen microbes when M. oleifera was present. M. oleifera leaves are known to contain high levels of sulphur-containing amino acids (Makkar \& Becker, 1997), and the S requirement of rumen microbes for the synthesis of its own S-containing amino acids is apparent (McSweeney \& Denman, 2007; Akinlade \& Ososanya, 2016).

Provision of additional nitrogen sources in the rumen or treating the cocoa pod husk biologically with $P$. chrysosporium and $P$. ostreatus had no effect on total or individual VFA concentrations and gas productions and parameters in the rumen (Table 4 and 5). The facts that the higher feed degradability was not followed with higher fermentation products might have indicated that the degraded feed organic matter was probably used for microbial biomass synthesis rather than being fermented. The presence of sulphur-containing amino acids in $M$. oleifera and higher ammonia concentrations may have promoted a more efficient microbial growth in the rumen.

\section{CONCLUSION}

It can be concluded that nutritional quality of cocoa pod husk can be improved by either bioconversion with $P$. chrysosporium and $P$. ostreatus or inclusion of $M$. oleifera and urea in the rumen, but the best improvement can be obtained by the combination of bioconversion and provision of the nitrogen sources in the rumen.

\section{REFERENCES}

Adegun, M.K., P.A. Aye, \& F.A.S. Dairo. 2011. Evaluation of Moringa oleifera, Gliricidia sepium and Leucaena leucocephalabased multi nutrient blocks as feed supplements for sheep in South Western Nigeria. Agric. Biol. J. North Am. 2: 13951401. https://doi.org/10.5251/abjna.2011.2.11.1395.1401

Akinlade, A.T. \& T.O. Ososanya. 2016. Nutrient utilization, ruminal mircobial population and fermentation characteristics of West African Dwarf (WAD) rams fed ammonium sulphate fortified diets. J. Anim. Prod. Res. 28: 309-317.

Allen, S.A. \& E.L. Miller. 1976. Determination of nitrogen for microbial growth from the effect of urea supplementation of a low $\mathrm{N}$ diet on abomasal $\mathrm{N}$ flow and $\mathrm{N}$ recycling in wethers and lambs. Br J Nutr 36: 353-368. https://doi. org/10.1079/BJN19760092.

Asaolu, V., R. Binuomote, J. Akinlade, O. Aderinola, \& O. Oyelami. 2012. Intake and growth performance of West African dwarf goats fed Moringa oleifera, Gliricidia sepium and Leucaena leucocephala dried leaves as supplements to cassava peels. J. Biol. Agric. Healthc. 2: 76-88.

Babeker, E.A. \& Y.M. Abdalbagi. 2015. Effect of feeding different levels of Moringa oleifera leaves on performance, haematological, biochemical and some physiological parameters of Sudan Nubian goats. Online J. Anim. Feed Res 5: $50-61$.

Babiker, E.E., F.A.L. Juhaemi, K. Ghafoor, \& K.A Abdoun. 2017. Comparative study on feeding value of Moringa leaves as a partial replacement for alfalfa hay in ewes and goats. Livest Sci 195: 21-26. https://doi.org/10.1016/j. livsci.2016.11.010

Bachruddin, Z. 1996. Pengukuran pH dan Asam Lemak Terbang (Vollatile Fatty Acid - VFA) Cairan Rumen dengan Gas Khromatografi (Kursus Singkat Teknik Evaluasi Pakan Ruminansia). Fakultas Peternakan UGM, Yogyakarta.

Blummel M., H. Steinglass, \& K. Becker. 1997. The relationship between in-vitro gas production, in-vitro microbial biomass yield and $15 \mathrm{~N}$ incorporation and its implications for prediction of voluntary feed intake of roughages. Br J Nutr 72: 911-921. https://doi.org/10.1079/BJN19970089

Cruz G., M. Pirilä, H. Huuhtanen, L. Carrión, E. Alvarenga, \& R. L. Keiski. 2012. Production of activated carbon from cocoa (Theobroma cacao) pod husk. J Civil Environment Engg 2: 1-6. 2012, 2:2 http://dx.doi.org/10.4172/2165-784X.1000109.

Daud, Z., A.S.M. Kassim, A.M. Aripin, H. Awang, \& M.Z.M Hatta. 2013. Chemical composition and morphological of cocoa pod husks and cassava peels for pulp and paper production. Aust. J. Basic Appl. Sci. 7: 406-411

Directorate General of Estate Crops (DGEC). 2015. Tree Crops Estate of Indonesia (2014-2016). Indonesian Ministry of Agriculture, Jakarta.

General Laboratory Procedure. 1966. Department of Dairy Science. University of Wisconsin. Madison, USA.

Hume, I. D., R. J. Moir, \& M. Somers. 1970. Synthesis of microbial protein in the rumen. 1. Influence of the level of nitrogen intake. Aust J Agric Res 21: 283-296. http://dx.doi. org/10.1071/AR9700283.

Kholif, A.E., G.A. Gouda, T.A. Morsy, A.Z.M. Salem, S. Lopez, \& A.M. Kholif. 2015. Moringa oleifera leaf meal as a protein 
source in lactating goat's diets: Feed intake, digestibility, ruminal fermentation, milk yield and composition, and its fatty acids profile. Small Rum Res 129: 129-137. https://doi. org/10.1016/j.smallrumres.2015.05.007.

Laconi, E. B. \& A. Jayanegara. 2015. Improving nutritional quality of cocoa pod (Theobroma cacao) through chemical and biological treatments for ruminant feeding: in-vitro and invivo evaluation. Asian-Australas. J. Anim. Sci. 28: 343-350. https://doi.org/10.5713/ajas.13.0798.

Makkar, H.P.S. \& K. Becker. 1997. Nutrients and antiquality factors in different morphological parts of the Moringa oleifera tree. J Agric Sci. 128: 311-22. http://dx.doi.org/10.1017/ S0021859697004292

Makkar, H. P. S., M. Blümmel, \& K. Becker. 1995. Formation of complexes between poly vinyl pyrrolidones or polyethylene glycols and tannins, and their implication in gas production and true digestibility in in-vitro techniques. Br. J. Nutr. 73: 897-913. http://dx.doi.org/10.1079/BJN19950095.

McSweeney, C.S \& S.E. Denman. 2007. Effect of sulfur supplements on cellulolytic rumen micro-organisms and microbial protein synthesis in cattle fed a high fibre diet. J. Appl. Microbiol. 103: 1757-1763. https://doi. org/10.1111/j.1365-2672.2007.03408.x

Mendieta-Araica, B., R. Sporndly, N.R. Sanchez, \& E. Sporndly. 2011. Moringa (Moringa oleifera) leaf meal as a source of protein in locally produced concentrates for dairy cows fed low protein diets in tropical areas. Livest. Sci. 137: 10-17. https://doi.org/10.1016/j.livsci.2010.09.021

Menke, K. H., L. Raab, A. Salewski, H. Steingass, D. Fritz, \& W. Schneider. 1979. The estimation of the digestibility and metabolizable energy content of ruminant feeding stuffs from the gas production when they are incubated with rumen liquor. J Agric Sci 93: 217-222. https://doi.org/10.1017/ S0021859600086305

Ørskov, E. R. \& I. McDonald. 1979. The estimation of protein degradability in the rumen from incubation measurements weighted according to rate of passage. J Agric Sci 92: 499503. https://doi.org/10.1017/S0021859600063048

Preston, T. R. \& R. A. Leng. 1987. Matching Ruminant Production Systems with Available Resources in the Tropics and Sub-Tropics. Penambul Books, Armidale.

Puastuti, W. \& I.W.R. Susana. 2014. Potency and utilization of cocoa pod husk as an alternative feed for ruminants. Wartazoa 24: 151-159. https://doi.org/10.14334/wartazoa. v24i3.1072

Saili, T, Marsetyo, D.P. Poppi, P. Isherwood, L. Nafiu, \& S.P. Quigley. 2010. Effect of treatment of cocoa-pods with Aspergillus niger on liveweight gain and cocoa-pod intake of Bali (Bos sondaicus) cattle in South-East Sulawesi. Ani. Prod. Sci. 50: 693-698. https://doi.org/10.1071/AN09193

Suparjo, K. G. Wiryawan, E. B. Laconi, \& D. Mangunwidjaja. 2011. Performa kambing yang diberi kulit buah kakao terfermentasi. Med Pet 34: 35-41. https://doi.org/10.5398/ medpet.2011.34.1.35
Satter, L. D. \& L. L. Slyter. 1974. Effect of ammonia concentration on rumen microbial protein production in-vitro. Br. J. Nutr. 32:199-208. https://doi.org/10.1079/BJN19740073

Soliva, C.R., M. Kreuzer, N. Foidl, G. Foidl, A.Machmüller, \& H.D.Hess. 2005. Feeding value of whole and extracted Moringa oleifera leaves for ruminants and their effects on ruminal fermentation in-vitro. J. Ani. Feed Sci. Tech. 118: 47-62. https://doi.org/10.1016/j.anifeedsci.2004.10.005

Steel, R.G.D. \& J.H. Torrie. 1991. Prinsip dan prosedur statistik, suatu pendekatan biometrik. terjemahan. judul asli : Principles and procedures of statistic, a biometrical approach. Penerjemah : Bambang Sumantri. Gramedia Pustaka Utama, Jakarta.

Sultana, N., A. R. Alimon, K.S. Huque, A.Q. Sazili, H. Yaakub, J. Hossain, \& M. Baba. 2015. The feeding value of moringa (Moringa oleifera) foliage as replacement to conventional concentrate diet in Bengal goats. Adv. Anim. Vet. Sci. 3: 164173. https://doi.org/10.14737/journal.aavs/2015/3.3.164.173

Syahrir, Hartutik, Kusmartono, \& Damry. 2013. Effects of cocoa pod husk bioconversion with Phanerochaete chrysosporium and or Pleurotus ostreatus on its nutrient content and in-vitro digestibility in ruminants. Livestock Research for Rural Development. Volume 25, Article \#122. Retrieved July 17, 2017, from http://www.lrrd.org/lrrd25/7/syah25122.htm

Syarifuddin, N.A., A. L. Toleng, D. P. Rahardja, I. Ismartoyo, \& M. Yusuf. 2017. Improving libido and sperm quality of Bali bulls by supplementation of Moringa oleifera leaves. Med Pet 40: 88-93. https://doi.org/10.5398/medpet.2017.40.2.88

Tilley, J. M. A. \& R.A. Terry. 1963. A two stage technique for invitro digestion of forage crop. J. Br. Grassl. Soc. 18: 104-114. https://doi.org/10.1111/j.1365-2494.1963.tb00335.x

van Der Meer, J. M. 1980. Determination of the in-vitro digestibility for the prediction of the in-vivo organic matter digestibility coefficient of feeds for ruminants. Documentation Report No. 67. IVVO, Lelystad.

van Kuijk, S.J.A., A.S.M. Sonnenberg, J.J.P. Baars, W.H. Hendriks, \& J.W. Cone. 2014. Fungal treated lignocellulosic biomass as ruminant feed ingredient: A review. Biotechnol Adv 33: 191-202. https://doi.org/10.1016/j. biotechadv.2014.10.014

Witjaksono, J. \& Asmin. 2016. Cocoa farming system in Indonesia and its sustainability under climate change. Agriculture, Forestry and Fisheries 5: 170-180. https://doi. org/10.11648/j.aff.20160505.15

Yakin, E.A., Z. Bachruddin, R. Utomo, \& R. Millati. 2016. Effect of white rot fungi to enzimatic activity and lignin on fermentation process of cocoa pod. J. Biol. Agric. Healthc. 6: 47-50.

Yakin, E.A., Z. Bachruddin, R. Utomo, \& R. Millati. 2017. Effect of lignocellulolytic fungus on enzimatic activity, fiber fraction, and digestibility on fermentation process of cocoa pod. Bull Ani Sci 41: 250-256. https://doi.org/10.21059/buletinpeternak.v41i3.22657 